\title{
Frequency of Low Vitamin D3 Levels in Subjects with Parkinson's Disease. A Study Conducted at PMCH, a Tertiary Care Hospital, Nawabshah
}

\author{
Anwar Ali Jamali1 ${ }^{*}$, Ghulam Mustafa Jamali', Bhojo Mal Tanwani², Niaz Hussain Jamali², \\ Moti Ram Bhatia ${ }^{3}$
}

\begin{abstract}
${ }^{1}$ Department of Medicine, Peoples Medical University of Medical and Health Sciences, Nawabshah, Sindh, Pakistan ${ }^{2}$ Department of Physiology, Peoples Medical University of Medical and Health Sciences, Nawabshah, Sindh, Pakistan ${ }^{3}$ Department of Psychiatry, Peoples Medical University of Medical and Health Sciences, Nawabshah, Sindh, Pakistan Email: ‘jamalianwarali@gmail.com,dr_mustafa_jamali72@yahoo.com, bhojomal@hotmail.com,niazhussain858@yahoo.com, drbhatia_pn@yahoo.com
\end{abstract}

How to cite this paper: Jamali, A.A., Jamali, G.M., Tanwani, B.M., Jamali, N.H. and Bhatia, M.R. (2018) Frequency of Low Vitamin D3 Levels in Subjects with Parkinson's Disease. A Study Conducted at PMCH, a Tertiary Care Hospital, Nawabshah. Advances in Parkinson's Disease, 7, 7-18. https://doi.org/10.4236/apd.2018.71002

Received: January 24, 2018

Accepted: February 23, 2018

Published: February 26, 2018

Copyright (C) 2018 by authors and Scientific Research Publishing Inc. This work is licensed under the Creative Commons Attribution International License (CC BY 4.0).

http://creativecommons.org/licenses/by/4.0/

\begin{abstract}
Background: Lack of serum vitamin D3 is related to PD (Parkinson's disease). Currently a valid place for vitamin D3 deficiency in Parkinson disease (PD) has been anticipated. The aim of present research was to evaluate insufficiency of D3 (vitamin) in subjects with PD (Parkinson's disease). Many of physiological functions connected with higher risk of illness are maintained by vitamin $\mathrm{D}$, which also plays significant task in pathogenesis of calcium homeostasis and skeletal ailments. It forecasts hazard of persistent ailments like malignancy, CVS conditions, and T2DM. Continuous insufficiency of this vitamin may lead to PD. Method: This was a cross sectional study. Conducted at People's Medical College Hospital, Nawabshah during period of Jan. 2014-Dec. 2016, the sample size of 243 subjects clinically diagnosed as PD was enlisted. Inclusion criteria were all male and female subjects aged $>50$ years, clinically diagnosed Parkinson's disease enlisted in research. Results: In $151(62.1 \%)$ subjects, vitamin D3 levels were $<30 \mathrm{ng} / \mathrm{ml}$ while in 92 (37.9\%) subjects, vitamin D3 values were normal $(30-150 \mathrm{ng} / \mathrm{ml})(\mathrm{p}=$ 0.000). Conclusion: Considerably low levels of vitamin D3 were seen in Parkinson's disease. Our information sustains a legitimate part of vitamin D insufficiency in PD.
\end{abstract}

\section{Keywords}

Parkinson's Disease, Vitamin D Deficiency, Nawabshah 


\section{Introduction}

Vitamin D, a fat-soluble vitamin, has many biological consequences. It increases absorption of calcium, phosphate and magnesium in gut. Vitamin D3 and D2 (Cholecalciferol, Ergocalciferol) are essential compounds in our body [1]. Parkinson's Disease is widespread neurological ailment of old age with unidentified cause. PD has great financial burden and social status of people universally. Uneven prevalence and incidence rates may be affected by ecological or hereditary components, approaches for case determination, diagnostic criterion, or age disseminations of investigation populaces may affect outcomes. Equivalence of existing researches is restricted [2]. Vitamin D3 assumes a critical part in pathogenesis of skeletal ailments and calcium homeostasis [3]. Vitamin D insufficiency likewise predicts expanded danger of other perpetual ailments, malignancy, [4], cardiovascular sicknesses [5] and DM (type 2) [6]. Constantly deficient vitamin $\mathrm{D}$ values promote a constant loss of dopaminergic neurons and propose to assume a major part in the pathogenesis of PD [7]. The epidemiological confirmation of a relationship among vitamin D and PD is, however, constrained to cross-sectional researches [8] [9] [10].

Studies had declared that in America (North), hundreds of populations who suffer from PD are vitamin D deficient. There is connection among PD and D3. These results have a strong correlation in old age peoples and fall risks and intimates additional search into the method essential for this connection [11]. Subjects with PD have decreased vitamin D concentrations in relation to controls. $\mathrm{PD}$ is a noteworthy reason for incapacity in older people. Biological credibility and epidemiological information show that vitamin $\mathrm{D}$ inadequacy may add to PD progression [7]. The recent research explored whether D3 level predicts Parkinson disease occurrence in populace of Pakistan where solar exposure is high from different zones of world. Vitamin D inadequacy had turned into universal issue in the older, kids and grown-ups [12] [13]. Lack of vitamin D3 can occur from decreased solar contact [14]. Altered bone mineralization and bony injury are associated with insufficiency leading to softening bony ailments (osteomalacia and rickets) [15] [16]. This study will help in future to manage PD patients properly by reducing risk, treating and avoiding complications by giving additional supplements of vitamin D as a primary step by adding the basic element to diet and as drug.

\section{Methods}

\subsection{Subjects and Setting}

A sum of 243 diagnosed PD subjects from local community enrolled during 2014 to 2016 attending Department of Medicine, People's Medical University Hospital Nawabshah, Sindh, Pakistan. Sample size calculated by OpenEpi version 3, with population size 1.6 million, hypothesized percent frequency of outcome factor in PD 66/100,000, with confidence level $90 \%$ and margin of error $10 \%$. Subjects with other neurodegenerative, thyroid ailments, and new change in life- 
style or nutritional status excluded. A questionnaire based interview and complete clinical examination performed in subjects. All aspects of research updated to subjects and signed consent obtained. Educational situation, routine daylight contact, cigarettes, alcohol, head injury, pesticide exposure and medical history taken by direct questions. This study conducted after authorization of Peoples Medical University Hospital ethical committee.

\subsection{Diagnoses of PD and Vitamin D3 Deficiency}

Parkinson's disease was diagnosed through UK PD Society Brain Bank clinical diagnostic criteria, [17] clinical history and relevant signs on examination of patients. Vitamin D3 deficiency diagnosed through laboratory analysis of blood samples of PD sufferers. Serum 25(OH)D concentrations $>30 \mathrm{ng} / \mathrm{ml}$ normal, $>20$ and $<30 \mathrm{ng} / \mathrm{ml}$ insufficiency and deficiency $<20 \mathrm{ng} / \mathrm{ml}$ [18].

A well-versed printed consent dully signed by subjects with diagnosis of PD obtained and gratifying inclusion criterion attending Medical Departments PMC Hospital Nawabshah. The venous blood drawn, sent to laboratory for analysis of serum Vitamin D3 by Mini Vidas Biomerieux Global Company France. Levels < $30 \mathrm{ng} / \mathrm{ml}$ were labeled as Hypovitaminosis D. After collection of investigations, serum Vitamin D3 levels in PD subjects were determined and proforma filled accordingly.

\subsection{Statistical Analysis}

The important outcome of study was assessment of vitamin D levels in subjects of PD. All gathered figures analyzed by Statistical Package for Social Science (SPSS) software, edition 20.0. Frequency \& percentages computed for categorical variables like gender, and Vitamin D levels. Mean and standard deviation considered for variables (quantitative) as age and vitamin D3 levels. Significance of serum Vitamin D was seen with age, gender, duration of PD to see the impact of these on outcomes. $\mathrm{P}$ value $<0.05$ was considered statistically significant. Variables (Clinical) communicated as mean \pm standard deviation (SD) or percentage as suitable. Chi-square test utilized to review distinctions in ratios. Affiliation among serum vitamin $\mathrm{D} 3, \mathrm{PD}$ and its duration were investigated by bivarate correlation analysis by changing for the covariates (age, sex, BMI, smoking, liquor utilize, pesticide history, BMI and vitamin D). The relationships between serum $25(\mathrm{OH}) \mathrm{D}$ and length of $\mathrm{PD}$ were examined by bivarate correlation investigation.

\section{Results}

\subsection{Analyses of Age and Vitamin D}

In recent study there were a total of 243 subjects with PD who were assessed for frequency of vitamin D deficiency. The Mean age of patients was 67.64 with SD \pm 6.67 years minimum 56 and maximum 85 years respectively. Mean values of vitamin D3 levels were 27.68 with $\mathrm{SD} \pm 21.72 \mathrm{ng} / \mathrm{ml}$ with minimum $08 \mathrm{ng} / \mathrm{ml}$ and maximum values $85.50 \mathrm{ng} / \mathrm{ml}$. 


\subsection{Analyses of Demographic Data}

Most participants were males $170(70 \%)$ and 73 (30\%) females, 232 (95.5\%) married and $11(4.5 \%)$ were unmarried $(\mathrm{p}=0.000)$. A large number of subjects $162(66.7 \%)$ were from rural and $81(33.3 \%)$ from urban community $(\mathrm{p}=0.000)$. By occupation 27 (11.1\%) have no any occupation, 73 (30\%) house-wives, 100 (41.2\%) manual workers and $43(17.7 \%)$ were office workers $(p=0.000)$. Regarding educational status $64(26.3 \%)$ uneducated, $123(50.6 \%)$ primary to matriculation, $48(19.8 \%)$ intermediate to graduation and only $08(3.3 \%)$ were postgraduates $(\mathrm{p}=0.000)$. A large number of study subjects $213(87.7 \%)$ had no any evidence of $\mathrm{PD}$ in family, where as positive family history was observed in $30(12.3 \%)$ subjects $(\mathrm{p}=0.000)$. Evaluating risk factors for PD, history of pesticide contact in 09 (3.7\%), smoking 61 (25.1\%), alcohol abuse 24 (9.9\%) and history of head injury observed in $18(7.4 \%)$ subjects $(\mathrm{p}=0.000)$. BMI normal in $143(58.8 \%)$, over weight in $91(37.4 \%)$ and $09(3.7 \%)$ were obese subjects ( $\mathrm{p}=$ 0.000). Baseline characteristics of participants as tremors, bradykinesia, speech changes, impaired posture and balance, rigidity and writing changes were observed in $67.1 \%, 10.7 \%, 6.2 \%, 5.8 \%, 5.3 \%$ and $4.9 \%$ respectively $(\mathrm{p}=0.000)$. Regarding duration of PD $82(33.7 \%)$ were $<01$ year, $40(16.5 \%) 1-2$ years, 41 (16.9\%) 2 - 5 years, $40(16.5 \%) 5-10$ years and $40(16.5 \%)$ had duration $>10$ years $(\mathrm{p}=0.000)$. We identified $151(62.1 \%)$ subjects with vitamin $25(\mathrm{OH}) \mathrm{D}<$ $30 \mathrm{ng} / \mathrm{ml}$, remaining $92(37.9 \%)$ have normal vitamin D3 values $(30-150 \mathrm{ng} / \mathrm{ml})$ $(\mathrm{p}=0.000)$. Insufficiency $(10-30 \mathrm{ng} / \mathrm{ml})$ found in $148(60.9 \%)$ and deficiency $(<10 \mathrm{ng} / \mathrm{ml})$ was seen in $03(1.2 \%)$ subjects $(\mathrm{p}=0.000)$. Rest of chi-square values and df were shown in Table 1.

\subsection{Analyses of Different Correlations}

The correlation of different variables assessed as shown in Table 2. We found that vitamin D3 levels $(\mathrm{p}=0.000)$ were strongly correlated with age $(\mathrm{p}=0.000)$, duration of $\mathrm{PD}(\mathrm{p}=0.000)$ these were statistically significant, and the analysis of other risk factors of PD were also assessed there was not significant correlation of various risk factors of $\mathrm{PD}$ and vitamin $\mathrm{D}$ deficiency like head injury ( $\mathrm{p}=$ $0.017)$ alcohol $(p=0.358)$, smoking $(p=0.566)$, pesticide contact $(p=0.512)$, family history $(\mathrm{p}=0.840)$ and BMI $(\mathrm{p}=0.572)$ as shown in Table 2 . The $\mathrm{p}$-value of less than 0.05 was considered statistically significant.

\section{Discussion}

Pakistan is underdeveloped country with poor control on population growth and lack of resources. There is lot of hindrances in the health management parameters. Here we had carried out a research on PD and vitamin D3 level. PD is disease of old age. Sun exposure is easily available and prevalent throughout the country except few areas. There is poor concept of sunbath. Our male population remains outdoors most of daytime for earning purpose. Burka/Parda is common hindrances of females for sun exposure. Head injury, pesticide exposure, 
Table 1. Frequency, percentage and chi-square values of study variables.

\begin{tabular}{|c|c|c|c|c|c|c|}
\hline Variable & Variables details & Frequency & Percent & Chi-Square & df & Asymp. Sig. \\
\hline Variable & Total & 243 & 100.0 & \multicolumn{3}{|c|}{ Non-parametric } \\
\hline \multirow{2}{*}{ Gender } & Male & 170 & 70.0 & \multirow{2}{*}{$38.720^{\mathrm{b}}$} & \multirow{2}{*}{1} & \multirow{2}{*}{0.000} \\
\hline & Female & 73 & 30.0 & & & \\
\hline \multirow[b]{2}{*}{ Marital status } & Married & 232 & 95.5 & \multirow{2}{*}{$200.992^{\mathrm{b}}$} & \multirow[b]{2}{*}{1} & \multirow[b]{2}{*}{0.000} \\
\hline & Unmarried & 11 & 4.5 & & & \\
\hline \multirow{2}{*}{ Address } & Rural & 162 & 66.7 & \multirow{2}{*}{$27.000^{\mathrm{b}}$} & \multirow{2}{*}{1} & \multirow{2}{*}{0.000} \\
\hline & Urban & 81 & 33.3 & & & \\
\hline \multirow{4}{*}{ Occupation } & No Occupation & 27 & 11.1 & \multirow{4}{*}{$51.765^{\mathrm{c}}$} & \multirow{4}{*}{3} & \multirow{4}{*}{0.000} \\
\hline & House Wife & 73 & 30.0 & & & \\
\hline & Manual Workers & 100 & 41.2 & & & \\
\hline & Office Workers & 43 & 17.7 & & & \\
\hline \multirow{4}{*}{ Education } & Uneducated & 64 & 26.3 & \multirow{4}{*}{$112.440^{c}$} & \multirow{4}{*}{3} & \multirow{4}{*}{0.000} \\
\hline & Primary To Matric & 123 & 50.6 & & & \\
\hline & Intermediate to Graduate & 48 & 19.8 & & & \\
\hline & Post Graduate & 8 & 3.3 & & & \\
\hline \multirow{2}{*}{ Family Hx } & Negative Family History PD & 213 & 87.7 & \multirow{2}{*}{$137.815^{\mathrm{a}}$} & \multirow{2}{*}{1} & \multirow{2}{*}{0.000} \\
\hline & Positive Family History PD & 30 & 12.3 & & & \\
\hline \multirow{2}{*}{ Pesticide contact $\mathrm{Hx}$} & Pesticide Contact Hx Yes & 9 & 3.7 & \multirow{2}{*}{$208.333^{b}$} & & \\
\hline & Pesticide Contact Hx No & 234 & 96.3 & & 1 & 0.000 \\
\hline Smoling Hy & Smoking Yes & 61 & 25.1 & $60251^{\mathrm{b}}$ & & \\
\hline H & Smoking No & 182 & 74.9 & . & 1 & 0.000 \\
\hline & Alcohol History No & 219 & 90.1 & & & \\
\hline AICOIOI ПX & Alcohol History Yes & 24 & 9.9 & 100.303 & 50 & 0.000 \\
\hline & Head Injury Yes & 18 & 7.4 & & & \\
\hline Head injury $\mathrm{Hx}$ & Head Injury No & 225 & 92.6 & $176.333^{\mathrm{b}}$ & 1 & 0.000 \\
\hline & Tremor & 163 & 67.1 & & & \\
\hline & Bradykinesia & 26 & 10.7 & & & \\
\hline & Speech Changes & 15 & 6.2 & & & \\
\hline PD symptoms & Impaired Posture \& Balance & 14 & 5.8 & $447.840^{\mathrm{e}}$ & 5 & 0.000 \\
\hline & Rigidity & 13 & 5.3 & & & \\
\hline & Writing Changes \& Others & 12 & 4.9 & & & \\
\hline & Deficiency: $0-10 \mathrm{ng} / \mathrm{ml}$ & 3 & 1.2 & & & \\
\hline Vit D & Insufficiency: 10 - $30 \mathrm{ng} / \mathrm{ml}$ & 148 & 60.9 & $209.704^{c}$ & 2 & 0.000 \\
\hline & Sufficiency: $30-150 \mathrm{ng} / \mathrm{ml}$ & 92 & 37.9 & & & \\
\hline & $<1$ & 82 & 33.7 & & & \\
\hline Duration of PD (Years) & $>1-2$ & 40 & 16.5 & $132.025^{\circ}$ & 4 & 0.000 \\
\hline
\end{tabular}




\begin{tabular}{|c|c|c|c|c|c|c|}
\hline & $>2-5$ & 41 & 16.9 & & & \\
\hline & $>5-10$ & 40 & 16.5 & & & \\
\hline & $>10$ & 40 & 16.5 & & & \\
\hline \multirow{3}{*}{ Vit D Level } & Normal & 92 & 37.9 & \multirow{3}{*}{$14.325^{\mathrm{b}}$} & \multirow{3}{*}{1} & \multirow{2}{*}{0.000} \\
\hline & Hypovitaminosis D & 151 & 62.1 & & & \\
\hline & Normal & 143 & 58.8 & & & \\
\hline \multirow[t]{2}{*}{ BMI } & Over Weight & 91 & 37.4 & $112.691^{\mathrm{a}}$ & 2 & 0.000 \\
\hline & Obese & 9 & 3.7 & & & \\
\hline
\end{tabular}

Table 2. Correlation of different variables in Parkinson's disease subjects. Correlations of low levels of Vitamin D levels with other variables of study.

\begin{tabular}{|c|c|c|c|c|c|c|c|c|c|c|}
\hline & & $\begin{array}{c}\text { Level of } \\
\text { vitamin D }\end{array}$ & $\begin{array}{c}\text { Duration } \\
\text { of } P D\end{array}$ & $\begin{array}{l}\text { Age in } \\
\text { years }\end{array}$ & $\begin{array}{l}\text { Hx of } \\
\text { head } \\
\text { injury }\end{array}$ & $\begin{array}{l}\text { Hx of } \\
\text { alcohol } \\
\text { intake }\end{array}$ & $\begin{array}{l}\text { Cigarette } \\
\text { smoking }\end{array}$ & $\begin{array}{c}\text { Pesticide } \\
\text { contact } \\
\mathrm{Hx}\end{array}$ & $\begin{array}{l}\text { Family } \\
\text { history }\end{array}$ & BMI \\
\hline \multirow{2}{*}{$\begin{array}{c}\text { Level of vitamin } \\
\text { D }\end{array}$} & Pearson Correlation & 1 & $-0.649^{* *}$ & $-0.656^{* *}$ & $0.153^{*}$ & -0.059 & -0.037 & -0.042 & 0.013 & 0.036 \\
\hline & Sig. (2-tailed) & & 0.000 & 0.000 & 0.017 & 0.358 & 0.566 & 0.512 & 0.840 & 0.572 \\
\hline \multirow{2}{*}{$\begin{array}{c}\text { Duration of } \\
\text { Parkinson's } \\
\text { disease }\end{array}$} & Pearson Correlation & $-0.649^{* *}$ & 1 & $0.814^{* *}$ & $-0.129^{*}$ & 0.021 & -0.077 & $0.130^{*}$ & -0.014 & 0.013 \\
\hline & Sig. (2-tailed) & 0.000 & & 0.000 & 0.045 & 0.742 & 0.232 & 0.043 & 0.832 & 0.840 \\
\hline \multirow{2}{*}{ Age in years } & Pearson Correlation & $-0.656^{\star *}$ & $0.814^{* *}$ & 1 & -0.065 & -0.030 & $-0.198^{\star *}$ & 0.019 & -0.098 & 0.004 \\
\hline & Sig. (2-tailed) & 0.000 & 0.000 & & 0.314 & 0.646 & 0.002 & 0.771 & 0.128 & 0.953 \\
\hline \multirow{2}{*}{$\begin{array}{l}\text { History of head } \\
\text { injury }\end{array}$} & Pearson Correlation & $0.153^{*}$ & $-0.129^{*}$ & -0.065 & 1 & -0.064 & $-0.164^{\star}$ & -0.055 & $-0.180^{\star \star}$ & 0.002 \\
\hline & Sig. (2-tailed) & 0.017 & 0.045 & 0.314 & & 0.318 & 0.011 & 0.389 & 0.005 & 0.975 \\
\hline \multirow{2}{*}{$\begin{array}{l}\text { History of alcohol } \\
\text { intake }\end{array}$} & Pearson Correlation & -0.059 & 0.021 & -0.030 & -0.064 & 1 & 0.001 & 0.065 & $0.882^{* *}$ & 0.030 \\
\hline & Sig. (2-tailed) & 0.358 & 0.742 & 0.646 & 0.318 & & 0.990 & 0.314 & 0.000 & 0.641 \\
\hline \multirow{2}{*}{$\begin{array}{l}\text { Cigarette } \\
\text { smoking }\end{array}$} & Pearson Correlation & -0.037 & -0.077 & $-0.198^{\star *}$ & $-0.164^{\star}$ & 0.001 & 1 & -0.114 & 0.044 & 0.006 \\
\hline & Sig. (2-tailed) & 0.566 & 0.232 & 0.002 & 0.011 & 0.990 & & 0.077 & 0.493 & 0.925 \\
\hline \multirow{2}{*}{$\begin{array}{l}\text { Pesticide contact } \\
\qquad \mathrm{hx}\end{array}$} & Pearson Correlation & -0.042 & $0.130^{*}$ & 0.019 & -0.055 & 0.065 & -0.114 & 1 & 0.074 & 0.001 \\
\hline & Sig. (2-tailed) & 0.512 & 0.043 & 0.771 & 0.389 & 0.314 & 0.077 & & 0.253 & 0.982 \\
\hline \multirow{2}{*}{ Family history } & Pearson Correlation & 0.013 & -0.014 & -0.098 & $-0.180^{* *}$ & $0.882^{* *}$ & 0.044 & 0.074 & 1 & 0.078 \\
\hline & Sig. (2-tailed) & 0.840 & 0.832 & 0.128 & 0.005 & 0.000 & 0.493 & 0.253 & & 0.225 \\
\hline \multirow{3}{*}{ Body Mass Index } & Pearson Correlation & 0.036 & 0.013 & 0.004 & 0.002 & 0.030 & 0.006 & 0.001 & 0.078 & 1 \\
\hline & Sig. (2-tailed) & 0.572 & 0.840 & 0.953 & 0.975 & 0.641 & 0.925 & 0.982 & 0.225 & \\
\hline & $\mathrm{N}$ & 243 & 243 & 243 & 243 & 243 & 243 & 243 & 243 & 243 \\
\hline
\end{tabular}

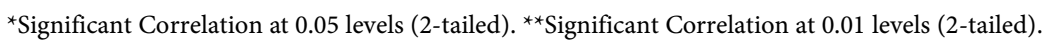

smoking are common in comparison to alcoholism and obesity in PD. Due to lack of health education, most of time peoples ignore health issues. Currentlyan established role of vitamin D and PD was identified. We carried out a study in our population to check the presence of low levels of vitamin D3 in PD. There is 
described role of vitamin D3 lack in PD, vitamin D3 insufficiency leads or progresses to Parkinson's disease. These issues were focused in different studies in rest of world. Findings of present study are match-able with previous studies as discussed below.

$\mathrm{PD}$ (Parkinson's disease) is a neurodegenerative disease in a particular zone of the cerebrum called substantia nigra, [19] characterized by inflexible nature, tremors and dyskinesia along with postural insecurity and dementia. Vitamin D had critical effect on neurological illnesses as PD and Dementia. In cerebrum, hippocampus and substantia nigra neurons show high convergences of VDRs in their core and 1-OHase in their cytosol. In present study mean \pm SD values of age were $67.64 \pm 6.67$ years (age range 56 - 85 years), males $170(70 \%)$ and 73 (30\%) were females, our findings are supported in a study by Moghaddasi $\mathrm{M}$ et al. in which mean age of the patients were $56.57 \pm 11.71$ years (age range $24-79$ years); 3 (75.9\%) males and $20(24.1 \%)$ were females. Mean age of symptoms onset was $50.71 \pm 12.10$ years (range 20 - 77 years) [20]. With insufficiency of vitamin $\mathrm{D}$, there is hazard of developing $\mathrm{PD}$; this hazard increases to twofold when there is deficiency of vitamin D [21]. Vitamin D levels were low in subjects with $\mathrm{PD}$ and $\mathrm{AD}$ in comparison to the normal controls, [8] current study also determined insufficiency of vitamin D3 in $61.1 \%$ of PD subjects. $25(\mathrm{OH}) \mathrm{D} 3$ emphatically connected with intellectual execution, especially with measuring its role in elderly populace [22]. Many of studies (Cross Sectional) had shown the relationship of decreased levels of vitamin $\mathrm{D}$ with incident of $\mathrm{PD}$ also predicted increased hazard of PD [23]. Vitamin D levels in high-risk group and matched controls (age, sex) did not differ, and it was suggested that there is no deficiency of vitamin D before diagnosis of PD [24]. A majority of researches in established PD had shown lower vitamin D values as compared to fit controls [9]. Serum values of vitamin D decrease as severity of disease increases [25] [26] as low levels of vitamin D3 were observed in subjects of PD in this study.

Nitric Oxide (free radical) can damage to cells, its synthesis is inhibited by vitamin D, and vitamin D3 also causes formation of glutathione (antioxidant) thus plays a neuro-protective role [27]. It is assumed that vitamin D3 is involved in initiating the synthesis of N G F (nerve growth factor), Glial cell line derived factor and NT3 (Neurotrophin) and in this way is considered as Neurotrophic Factor [28] [29] [30]. Peterson et al. in their research found strong relationship of automatic postural responses with serum vitamin D concentrations [31]. Daily vitamin D3 supplements (1200 IU) for one year showed mild progression of disease and worsening of disease observed in those who did not receive increments. [32] As there were presence of more than one symptom of PD, VDD was more common as age of patient increases with more than one symptom. Patients with PD had limited outdoor activities so solar exposure is decreased this may contributes to decreasing levels of vitamin D even with incremental intake [33].

Juan Wang et al. showed statistically a significant link among vitamin D values and sun exposure; and no involvement among serum vitamin D and daily 
oral supplements of vitamin D. There study indicated that low values of this vitamin with reduced sun exposure are associated with increase hazard of PD [34], above associations of VDD and PD are evident in present study. Yoon JH et al. in their study subjects with early PD, observed the relation among serum vitamin D values and endothelial cell dysfunction [35]. Probable racial variations in passageway for consumed vitamin D may be dilemma crossways to panel suggestions meant for D3 values as in Inuit. Decreased synthesis of this vitamin is balanced in Inuit through transforming lot of vitamin-D towards its chiefly active type [36]. A Toronto research on Canadians (young) from various origins had average vitamin D3 values that were fundamentally elevated from authorized proposals [37]. 22\% European, 78\% and 77\% of Asian (East, South) heritage had vitamin D3 level $<40 \mathrm{nmol} / \mathrm{l}(15 \mathrm{ng} / \mathrm{ml})$, compared with previous studies. Toronto study in Asians (East) observed decreased vitamin D3 in contrast with White community [38].

Rural men around Delhi had average $44 \mathrm{nmol} / \mathrm{L}$ of D3, in current study 162 (66.7\%) subjects from rural and $81(33.3 \%)$ were urban $(\mathrm{p}=0.000)$, with mean vitamin D3 levels $27.68 \pm 21.72 \mathrm{ng} / \mathrm{ml}$, these findings are matching with results of study by Rajasree $S$ et al. Normal Indians have decreased vitamin D3, not much unusual than Canadian Asians (South). South Indians with IHD had tremendously increased (>222.5 nmol/l) D3 values [39]. In present study with references to above studies we found that $151(62.1 \%)$ subjects have vitamin D3 $<30 \mathrm{ng} / \mathrm{ml}$ and remaining $92(37.9 \%)$ have sufficient D3 values $(30-150 \mathrm{ng} / \mathrm{ml})$ (p value 0.000$)$. Insufficiency $(10-30 \mathrm{ng} / \mathrm{ml})$ in $148(60.9 \%)$ and deficiency $(<10$ $\mathrm{ng} / \mathrm{ml})$ observed in $03(1.2 \%)$ subjects $(\mathrm{p}=0.000)$. Melanin substance demonstrated opposite association with serum 25(OH)D [37]. Uniformly deficient 25(OH)D values seen in Indians (living in India and China). Noteworthy Hereditary minority of French Canadians didn't buildup consumed vitamin D3. Vitamin D3 protein binding polymorphisms had a significant part of variety in serum D3 as totaled intake of vitamin D3 [40] [41]. Different methods controlling metabolism with limited extent of vitamin D values in which vascular capacity is streamlined were associated with increased mortality [42], abnormal functioning and premature aging [43].

Worldwide prevalence of vitamin D deficiency/insufficiency accounts for 1 billion people [13] where south Asians are uniformly affected despite abundant sunshine [44]. Pakistan a rising nation of Asia (South) with an area spreading over scope $24^{\circ} 35^{\prime}$ North and longitude $61^{\circ}$ East to $78^{\circ}$ East, seriously facing D3 insufficiency in pregnant ladies, neonates, babies, youngsters, teenagers, grown-ups, and elderly individuals regardless of plentiful daylight [45]. 70\% fit volunteers in Pakistan, $84 \%$ pregnant ladies in India are distressed by VDD. Sri Lanka and Bangladesh are no exception where $26 \%$ boys and $8 \%$ girls are victims of VDD [46]. A study demonstrated $66.32 \%$ of PD and $22.62 \%$ of healthy individuals had mild to moderate VDD (cutoff value $<30 \mathrm{ng} / \mathrm{ml}$ ). Pakistani population in general had VDD and vitamin D supplementation assumed to be added after clinical 
evaluation of population groups [47]. Mansoor et al. elucidated that $56.9 \%$ men and $43.1 \%$ normal women had Vitamin D3 $<20 \mathrm{ng} / \mathrm{ml}$ [48]. Sheikh et al. observed in $84.3 \%$ of tested healthy subjects (38 - 55 years) in Karachi had 25(OH)D levels $<30 \mathrm{ng} / \mathrm{ml}$ suggesting extensive VDD prevalence throughout Pakistan declaring Pakistani population a vitamin D deficient [49].

Findings of above studies were considerably in contest with present study where we identified 151 (62.1\%) subjects have vitamin D3 $<30 \mathrm{ng} / \mathrm{ml}$. A narrowed danger of death in old age observed with high Vitamin D3 levels while others didn't benefit [50]. Taking supplements are valuable or not still unclear [51]. Increased danger of vitamin D deficiency observed in Blacks comparison to White populace [52]. Further studies needed to find out reasons for these differences and clarify probable part of vitamin $\mathrm{D}$ in pathogenesis and clinical path of PD.

\section{Conclusion}

Vitamin D deficiency is commonly associated in patients suffering from Parkinson's disease. As concluded in present research that as the age advances, risk of Parkinson's disease increases with simultaneous decrease in vitamin D level. As concluded in our study, $62.1 \%$ subjects of Parkinson's disease were vitamin D deficient.

\section{References}

[1] Holick, M.F. (2006) High Prevalence of Vitamin D Inadequacy and Implications for Health. Mayo Clinic Proceedings, 81, 353-373. https://doi.org/10.4065/81.3.353

[2] Von Campenhausen, S., Bornschein, B., Wick, R., Bötzel, K., et al. (2005) Prevalence and Incidence of Parkinson's Disease in Europe. European Neuropsychopharmacology, 15, 473-490. https://doi.org/10.1016/j.euroneuro.2005.04.007

[3] Grant, W.B. (2006) Epidemiology of Disease Risks in Relation to Vitamin D Insufficiency. Progress in Biophysics and Molecular Biology, 92, 65-79. https://doi.org/10.1016/j.pbiomolbio.2006.02.013

[4] Kilkkinen, A., Knekt, P., Heliovaara, M., et al. (2008) Vitamin D Status and the Risk of Lung Cancer: A Cohort Study in Finland. Cancer Epidemiology, Biomarkers \& Prevention, 17, 3274-3278. https://doi.org/10.1158/1055-9965.EPI-08-0199

[5] Giovannucci, E., Liu, Y., Hollis, B.W. and Rimm, E.B. (2008) 25-Hydroxyvitamin D and Risk of Myocardial Infarction in Men: A Prospective Study. Arch Intern Med, 168, 1174-1180. https://doi.org/10.1001/archinte.168.11.1174

[6] Knekt, P., Laaksonen, M., Mattila, C., et al. (2008) Serum Vitamin D and Subsequent Occurrence of Type 2 Diabetes. Epidemiology, 19, 666-671. https://doi.org/10.1097/EDE.0b013e318176b8ad

[7] Newmark, H.L. and Newmark, J. (2007) Vitamin D and Parkinson's Disease-A Hypothesis. Movement Disorders, 22, 461-468. https://doi.org/10.1002/mds.21317

[8] Evatt, M.L., Delong, M.R., Khazai, N., et al. (2008) Prevalence of Vitamin D Insufficiency in Patients with Parkinson Disease and Alzheimer Disease. Arch Neurol, 65 1348-1352. https://doi.org/10.1001/archneur.65.10.1348

[9] Sato, Y., Honda, Y., Iwamoto, J., et al. (2005) Abnormal Bone and Calcium Metabolism in Immobilized Parkinson's Disease Patients. Movement Disorders, 20, 1598-1603. 
https://doi.org/10.1002/mds.20658

[10] Sato, Y., Kikuyama, M. and Oizumi, K. (1997) High Prevalence of Vitamin D Deficiency and Reduced Bone Mass in Parkinson's Disease. Neurology, 49, 1273-1278. https://doi.org/10.1212/WNL.49.5.1273

[11] Hongliu, D., Kaltra, D., Kaitlin, C., et al. (2013) Unrecognized Vitamin D3 Deficiency Is Common in Parkinson Disease: Harvard Biomarker Study. American Academy of Neurology, 81, 1531-1537.

[12] Eriksen, E.F. and Glerup, H. (2002) Vitamin D Deficiency and Aging: Implications for General Health and Osteoporosis. Biogerontology, 3, 73-77. https://doi.org/10.1023/A:1015263514765

[13] Holick, M.F. (2007) Vitamin D deficiency. The New England Journal of Medicine, 357, 266-281.

[14] Schoenmakers, I., Goldberg, G.R. and Prentice, A. (2008) Abundant Sunshine and Vitamin D Deficiency. The British Journal of Nutrition, 99, 1171-1173. https://doi.org/10.1017/S0007114508898662

[15] Grant, W.B. and Holick, M.F. (2005) Benefits and Requirements of Vitamin D for Optimal Health: A Review. Alternative Medicine Review, 10, 94-111.

[16] Brown, J.E., Isaacs, J., et al. (2013) Nutrition through the Life Cycle. Cengage Learning, Boston, MA. http://www.revolvy.com/main/index.php?s

[17] Hughes, A.J., Daniel, S.E., Kilford, L. and Lees, A.J. (1992) Accuracy of Clinical Diagnosis of Idiopathic Parkinson's Disease: A Clinico-Pathological Study of 100 Cases. Journal of Neurology, Neurosurgery \& Psychiatry, 55, 181-184. https://doi.org/10.1136/jnnp.55.3.181

[18] Shen, L. and Ji, H.F. (2015) Associations between Vitamin D Status, Supplementation, Outdoor Work and Risk of Parkinson's Disease: A Meta-Analysis Assessment. Nutrients, 7, 4817-4827. https://doi.org/10.3390/nu7064817

[19] Evatt, M.L., DeLong, M.R., Kumari, M., et al. (2011) High Prevalence of Hypovitaminosis D Status in Patients with Early Parkinson Disease. Archives of Neurology, 68, 314-319. https://doi.org/10.1001/archneurol.2011.30

[20] Moghaddasi, M., Mamarabadi, M. and Aghaii, M. (2013) Serum 25-Hydroxyvitamin D3 Concentration in Iranian Patients with Parkinson's Disease. Iranian Journal of Neurology, 12, 56-59.

[21] Lv, Z., Qi, H., Wang, L., et al. (2014) Vitamin D Status and Parkinson's Disease: A Systematic Review and Meta-Analysis. Neurological Sciences, 35, 1723-1730. https://doi.org/10.1007/s10072-014-1821-6

[22] Jennifer, S.B., Tammy, M.S., Bess, D.H., et al. (2009) The Journals of Gerontology: Series A, Vitamin D Is Associated with Cognitive Function in Elders Receiving Home Health Services. The Journals of Gerontology. Series A, Biological Sciences and Medical Sciences, 64, 888-895.

[23] Knekt, P., Kilkkinen, A., Rissanen, H., et al. (2010) Serum Vitamin D and the Risk of Parkinson Disease. Archives of Neurology, 67, 808-811. https://doi.org/10.1001/archneurol.2010.120

[24] Fullard, M.E., Xie, S.X., Marek, K., et al. (2017) Vitamin D in the Parkinson Associated Risk Syndrome (PARS) Study. Movement Disorders, 32, 1636-1640. https://doi.org/10.1002/mds.27127

[25] Rimmelzwaan, L.M., van Schoor, N.M., Lips, P., et al. (2016) Systematic Review of the Relationship between Vitamin D and Parkinson's Disease. Journal of Parkinson's Disease, 6, 29-37. https://doi.org/10.3233/JPD-150615 
[26] Ding, H., Dhima, K., Lockhart, K., et al. (2013) Unrecognized Vitamin D3 Deficiency Is Common in Parkinson Disease: Harvard Biomarker Study. Neurology, 81, 1531-1537. https://doi.org/10.1212/WNL.0b013e3182a95818

[27] Garcion, E., Wion-Barbot, N., Montero-Menei, C.N., et al. (2002) New Clues about Vitamin D Functions in the Nervous System. Trends in Endocrinology Metabolism, 13, 100-105. https://doi.org/10.1016/S1043-2760(01)00547-1

[28] Naveilhan, P., Neveu, I., Wion, D. and Brachet, P. (1996) 1,25-Dihydroxyvitamin D3, an Inducer of Glial Cell Line-Derived Neurotrophic Factor. Neuroreport, 7, 2171-2175. https://doi.org/10.1097/00001756-199609020-00023

[29] Musiol, I.M. and Feldman, D. (1997) 1,25-Dihydroxyvitamin D3 Induction of Nerve Growth Factor in L929 Mouse Fibroblasts: Effect of Vitamin D Receptor Regulation and Potency of Vitamin D3 Analogs. Endocrinology, 138, 12-18. https://doi.org/10.1210/endo.138.1.4858

[30] Neveu, I., Naveilhan, P., Baudet, C., Brachet, P. and Metsis, M. (1994) 1, 25-Dihydroxyvitamin D3 Regulates NT-3, NT-4 but Not BDNF mRNA in Astrocytes. Neuroreport, 6, 124-126. https://doi.org/10.1097/00001756-199412300-00032

[31] Peterson, A.L., Mancini, M. and Horak, F.B. (2013) The Relationship between Balance Control and Vitamin D in Parkinson's Disease-A Pilot Study. Movement Disorders, 28, 1133-1137. https://doi.org/10.1002/mds.25405

[32] Suzuki, M., Yoshioka, M., Hashimoto, M., et al. (2013) Randomized, Double-Blind, Placebo-Controlled Trial of Vitamin D Supplementation in Parkinson Disease. The American Journal of Clinical Nutrition, 97, 1004-1013. https://doi.org/10.3945/ajcn.112.051664

[33] Miyake, Y., Tanaka, K., Fukushima, W., et al. (2011) Lack of Association of Dairy Food, Calcium, and Vitamin D Intake with the Risk of Parkinson's Disease: A Case Control study in Japan. Parkinsonism \& Related Disorders, 17, 112-116. https://doi.org/10.1016/j.parkreldis.2010.11.018

[34] Juan, W., Deyu, Y., Yu, Y., et al. (2016) Vitamin D and Sunlight Exposure in Newly-Diagnosed Parkinson's Disease. Nutrients, 8, 142.

https://doi.org/10.3390/nu8030142

[35] Yoon, J.H., Park, D.K., Yong, S.W. and Hong, J.M. (2015) Vitamin D Deficiency and Its Relationship with Endothelial Dysfunction in Patients with Early Parkinson's Disease. Journal of Neural Transmission (Vienna), 122, 1685-1691. https://doi.org/10.1007/s00702-015-1452-y

[36] Rejnmark, L., Jørgensen, M.E., Pedersen, M.B., et al. (2004) Vitamin D Insufficiency in Greenlanders on a Westernized Fare: Ethnic Differences in Calcitropic Hormones between Greenlanders and Danes. Calcified Tissue International, 74, 255-263. https://doi.org/10.1007/s00223-003-0110-9

[37] Gozdzik, A., Barta, J.L., Wu, H., et al. (2008) Low Wintertime Vitamin D Levels in a Sample of Healthy Young Adults of Diverse Ancestry Living in the Toronto Area: Associations with Vitamin D Intake and Skin Pigmentation. BMC Public Health, 8, 336. https://doi.org/10.1186/1471-2458-8-336

[38] Abnet, C.C., Chen, W., Dawsey, S.M., et al. (2007) Serum 25(OH)-Vitamin D Concentration and Risk of Esophageal Squamous Dysplasia. Cancer Epidemiology, Biomarkers \& Prevention, 16, 1889-1893. https://doi.org/10.1158/1055-9965.EPI-07-0461

[39] Rajasree, S., Rajpal, K., Kartha, C.C., et al. (2001) Serum 25-Hydroxyvitamin D3 Levels Are Elevated in South Indian Patients with Ischemic Heart Disease. European Journal of Epidemiology, 17, 567-571. 
https://doi.org/10.1023/A:1014559600042

[40] Sinotte, M., Diorio, C., Bérubé, S., Pollak, M. and Brisson, J. (2009) Genetic Polymorphisms of the Vitamin D Binding Protein and Plasma Concentrations of 25-Hydroxyvitamin D in Premenopausal Women. The American Journal of Clinical Nutrition, 89, 634-640. https://doi.org/10.3945/ajen.2008.26445

[41] Labuda, M., Labuda, D., Korab-Laskowska, M., et al. (1996) Linkage Disequilibrium Analysis in Young Populations: Pseudo-Vitamin D-Deficiency Rickets and the Founder Effect in French Canadians. American Journal of Human Genetics, 59, 633-643.

[42] Hsu, J.J., Tintut, Y. and Demer, L.L. (2008) Vitamin D and Osteogenic Differentiation in the Artery Wall. Clinical Journal of the American Society of Nephrology, 3, 1542-1547. https://doi.org/10.2215/CJN.01220308

[43] Tuohimaa, P. (2009) Vitamin D and Aging. The Journal of Steroid Biochemistry and Molecular Biology, 114, 78-84. https://doi.org/10.1016/j.jsbmb.2008.12.020

[44] Harinarayan, C.V., et al. (2009) Vitamin D Status in India-Its Implications and Remedial Measures. A Review of over 50 Studies of 25(OH)D. Journal of the Association of Physicians of India, 57, 40-48. http://www.japi.org/jan_2009/R-1.html

[45] Akhtar, S. (2016) Prevalence and Correlates of Vitamin D Deficiency-Perspectives from Pakistan. MINI REVIEW. Department of Food Science and Technology, Bahauddin Zakariya University, Multan, Pakistan. Pakistan Journal of Pharmaceutical Sciences, 29, 1325-1330.

[46] Akhtar, S. (2016) Vitamin D Status of South Asian Populations-Risks and Opportunities. Critical Reviews in Food Science and Nutrition, 56, 1925-1940. https://doi.org/10.1080/10408398.2013.807419

[47] Anjum, P., Safder, N., Khalid, M. and Mehboob, I. (2013) Vitamin D Deficiency in Pakistani Population. Journal of Pakistan Orthopaedic Association, 25, 18-19.

[48] Mansoor, S., Habib, A., Ghani, F., et al. (2010) Prevalence and Significance of Vitamin D Deficiency and Insufficiency among Apparently Healthy Adults. Clinical Biochemistry, 43, 1431-1435. https://doi.org/10.1016/j.clinbiochem.2010.09.022

[49] Sheikh, A., Saeed, Z., Jafri, S.A.D., et al. (2012) Vitamin D Levels in Asymptomatic Adults-A Population Survey in Karachi, Pakistan. PLoS ONE, 7, e33452. https://doi.org/10.1371/journal.pone.0033452

[50] Bjelakovic, G., Gluud, L.L., Nikolova, D., et al. (2014) Vitamin D Supplementation for Prevention of Mortality in Adults. The Cochrane Database of Systematic Reviews (Systematic Review), 1, CD007470. https://doi.org/10.1002/14651858.CD007470.pub3

[51] Bolland, M.J., Grey, A., Gamble, G.D. and Reid, I.R. (2014) The Effect of Vitamin D Supplementation on Skeletal, Vascular, or Cancer Outcomes: A Trial Sequential Meta-Analysis. The Lancet Diabetes \& Endocrinology (Meta-Analysis), 2, 307-320. https://doi.org/10.1016/S2213-8587(13)70212-2

[52] Ross, A.C., Taylor, C.L., Yaktine, A.L. and Del Valle, H.B. (2011) Dietary Reference Intakes for Calcium and Vitamin D. National Academies Press, Washington, D.C. 